\title{
Minimum Length Number
}

National Cancer Institute

\section{Source}

National Cancer Institute. Minimum Length Number. NCI Thesaurus. Code C42697.

Indicates the least number of characters permissible in a value. 